\title{
Characterization of a Mahamayuri Vidyarajni Sutra excavated in Lu'an, China
}

\author{
Liu Liu ${ }^{1,2}$, Decai Gong $2^{2^{*}}$, Zhengquan Yao ${ }^{3}$, Liangjie Xu ${ }^{4}$, Zhanyun Zhu ${ }^{1}$ and Tonia Eckfeld ${ }^{1,5}$
}

\begin{abstract}
Historically, sutras played an important role in spreading Buddhist faith and doctrine, and today these remain important records of Buddhist thought and culture. A Mahamayuri Vidyarajni Sutra with polychrome paintings was found inside the cavity on top of the Nanmen Buddhist pagoda, built in the early Tang dynasty (618-627 CE) and located in Anhui Province, China. Textile was found on the preface which is strongly degraded and fragile. Unfortunately, the whole sutra is under severe degradation and is incomplete. Technical analysis based on scientific methods will benefits the conservation of the sutra. Optical microscopy (OM), micro-Raman spectroscopy combined with optical microscope (Raman), scanning electron microscopy in combination with energy dispersive X-ray analysis (SEM-EDS) and Fourier Transform Infrared Spectroscopy (FTIR) were used to characterize the pigment and gilded material, as well as the paper fiber and textile. Pigments such as cinnabar, minium, paratacamite, azurite, lead white were found. Gilded material was identified as gold. A five-heddle warp satin, made of silk, was found as the textile on the preface of the sutra. The sutra's preface and inner pages were made of paper comprised of bamboo and bark. As a magnificent yet recondite treasure of Buddhism, the sutra was analyzed for a better understanding of the material. A conservation project of the sutra will be scheduled accordingly.
\end{abstract}

Keywords: Sutra, Pigment, Micro-Raman spectroscopy, Conservation

\section{Introduction}

Nanmen Buddhist pagoda, located in Luan city, Anhui province, China, was built in 618-627 CE during the early Tang dynasty, with restoration carried out in Song dynasty (960-1279 CE) and again in the Qing dynasty (1636-1912 CE) [1]. In 2010, further restoration of the pagoda revealed a stone reliquary box in a cavity at its top. Writing in red pigment on the box lid records that the box was made in October, 1834 (during the Qing dynasty). The characters also state that a Mahamayuri Vidyarajni Sutra $(36 \mathrm{~cm} * 16 \mathrm{~cm})$ was stored inside the box, for the purpose of fostering peace and safety. The Mahamayuri Vidyarajni Sutra was an early text translated from Sanskrit into Chinese, with a total of six different translated versions in Chinese language; it has also been translated from Sanskrit into Nepali and Japanese

\footnotetext{
${ }^{*}$ Correspondence: gdclucky@ustc.edu.cn

${ }^{2}$ Basic Research Center of Conservation Science, Department of History of Science and Scientific Archaeology, University of Science and Technology of China, Hefei 230026, China

Full list of author information is available at the end of the article
}

[2-4]. The cult of Mahamayuri Vidyarajni endured for more than 600 years, starting in the Tang dynasty. Mahamayuri Vidyarajni (Great Peacock Wisdom Queen), known in China as Kongque Mingwang, is a protective Buddhist female guardian with the special function to prevent or cure injuries caused by poison [5].

The sutra and statues of Mahamayuri Vidyarajni have been found in the Mogao Grottoes of Dunhuang and the Dazu Stone Carvings in Chongqing. Importantly, the sutra found in Nanmen pagoda, is the first example of a Mahamayuri Vidyarajni Sutra to be found in central China [6].

The sutra found in the box has both exquisite polychrome paintings and characters, but is suffering from severe degradation. Ash on some pages and absence of several parts indicate the sutra has experienced fire. Deformation and shrinkage are also apparent, causing the adhesion of some pages to each other. Degradation of the polymer chain of the paper has resulted in its loss of strength. All of damage mentioned above puts the sutra into a dangerous situation. Fortunately, a part of the 
sutra with paintings of Buddhist stories survived. Various colors such as blue, green, black and red were found in the paintings, giving them an exquisite and vivid appearance (Fig. 1a, c, d). Textile was found on the preface which is strongly degraded and fragile (Fig. 1b).

Technical studies of other sutras have been reported for the purpose of identification and conservation. SEMEDS, XRD, Raman Spectroscopy and XRF were applied to the identification of pigment and paper fiber in ancient tripitaka, while enzyme-linked immunosorbent assay combined with FTIR was used in characterization of proteinaceous binders and organic coating of tripitaka $[7,8]$. Accelerator mass spectrometry radiocarbon was applied in the dating of ancient Japanese sutras with the results corresponding to the historical ages recorded on the artefacts $[9,10]$. Analysis by means of a minimally invasive, multi-analytical approach based on micro-Raman spectroscopy will inform the information of the sutra [11]. In this work, micro-Raman spectroscopy combined with several other techniques were applied to investigate the sutra, for a better understanding of the materials used in the sutra, as well as offering basic information for restoration.

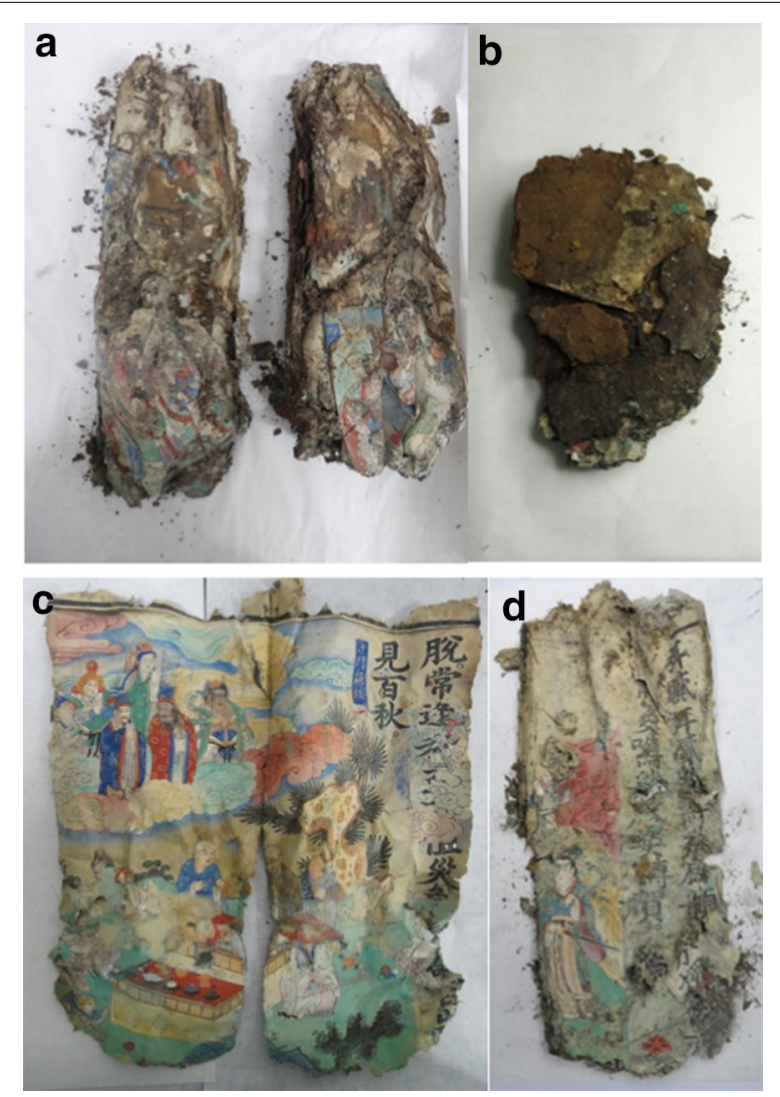

Fig. 1 Pages of the sutra (a total view of the sutra, $\mathbf{b}$ textile on the preface, $\mathbf{c}, \mathbf{d}$ pages of the sutra)

\section{Materials and methods Materials}

A non-invasive approach is preferred in the field of cultural heritage. Due to the lacking of portable equipment, five different fragment samples were carefully selected from the fallen part of the sutra for non (micro)-destructive analysis (Table 1). Pigments with different color (red, light red, green, blue, white) were found. Gilded material was also collected. Fiber from paper and textile were selected for analysis.

\section{Methods \\ Optical microscopy}

Microscopic studies of the pigment were based on a KEYENCE VHX-2000C microscope for micromorphology observation. Paper fiber was observed under a XWY-VI fiber analysis microscope. Sample preparation of paper fiber was by following steps: dispersing the paper fiber into water, putting the single fiber on a glass slide and dyeing the fiber with $\mathrm{I}_{2}-\mathrm{ZnCl}_{2}$ solution [12].

\section{Micro Raman spectroscopy}

Micro-Raman analysis of the pigment was performed by a LabRam spectrometer (purchased from Horiba Jobin-Yvon, France) coupled with a microscope. Point measurements were performed using an argon gas laser at $514.5 \mathrm{~nm}$ and a $50 \times$ working distance objective. The spectral resolution was $0.6 \mathrm{~cm}^{-1}$. The laser power used was approximately $0.5 \mathrm{~mW}$, which ensured that goodquality spectra was recorded. The system used a thermoelectrically cooled CCD detector, which operated at $-65^{\circ} \mathrm{C}$, and an 1800 groove/ $\mathrm{mm}$ dispersive grating.

\section{SEM-EDS}

SEM-EDS was used for element characterization of pigment and morphological observation of textile fiber. Due to the limited choice of analysis equipment, a micro-destructive method SEM-EDS was chosen instead of XRF for element characterization. A small particle of pigment (less than $1 \mathrm{~mm}$ ) was selected under microscope for analysis. The instrument used for SEM-EDS analysis was a Sirion 200 of the FEI Company, USA. Samples were analyzed with $20 \mathrm{kV}$ acceleration voltage and $5 \mathrm{~mm}$ working distance. Fibers of the textile were cut by a fiber slicer to achieve the cross section for observation. A steamed gold process was carried out on pigment samples and textile sample due to their poor conductivity. The process was not used in the gilded sample.

FTIR

A non-destructive method by ATR-FTIR was used to classify the textile fiber with 64 scans over the range of $4000-700 \mathrm{~cm}^{-1}$ by a Nicolet- 6700 instrument, the resolution is $4 \mathrm{~cm}^{-1}$. 
Table 1 Sample collection

\begin{tabular}{|c|c|c|c|}
\hline $\begin{array}{l}\text { Sample } \\
\text { number }\end{array}$ & Sample Photo & Description & Pigment for Analysis \\
\hline \multirow[t]{2}{*}{1} & & $\begin{array}{l}\text { At least two pages are stuck } \\
\text { together. }\end{array}$ & $\begin{array}{c}\text { Red and green area, } \\
\text { paper fiber of inner page }\end{array}$ \\
\hline & $1 \mathrm{~cm}$ & & \\
\hline 2 & & $\begin{array}{l}\text { Gold is found on the surface } \\
\text { in the patterned area. }\end{array}$ & $\begin{array}{l}\text { Light red area and gold } \\
\text { area }\end{array}$ \\
\hline 3 & & $\begin{array}{l}\text { The whole sample is } \\
\text { darkened. }\end{array}$ & Blue area \\
\hline 4 & & $\begin{array}{c}\text { Fiber is adhered to the } \\
\text { sample. }\end{array}$ & White area \\
\hline 5 & & Preface of the sutra. & Textile and paper fiber \\
\hline & $1 \mathrm{~cm}$ & & \\
\hline
\end{tabular}

\section{Results and discussion}

\section{Microscopic observation of pigments}

Plenty of colors were observed (Fig. 2). White particles (identified as $\mathrm{SiO}_{2}$ and calcium salt later) and minerals were found on the surface of the samples. Cracks also appeared on the surface of the pigment (Fig. 2b, $\mathrm{f})$, indicating that the samples are in poor condition.
Pigments have dropped off from the fiber (Fig. 2a, c), possibly caused by the failure of binding materials. Loss of pigment makes the color inhomogeneous and therefore the illustrations within the sutra are incomplete. Gilding was frequently used in the illustrations, which is the indicative of the sutra's high value. 

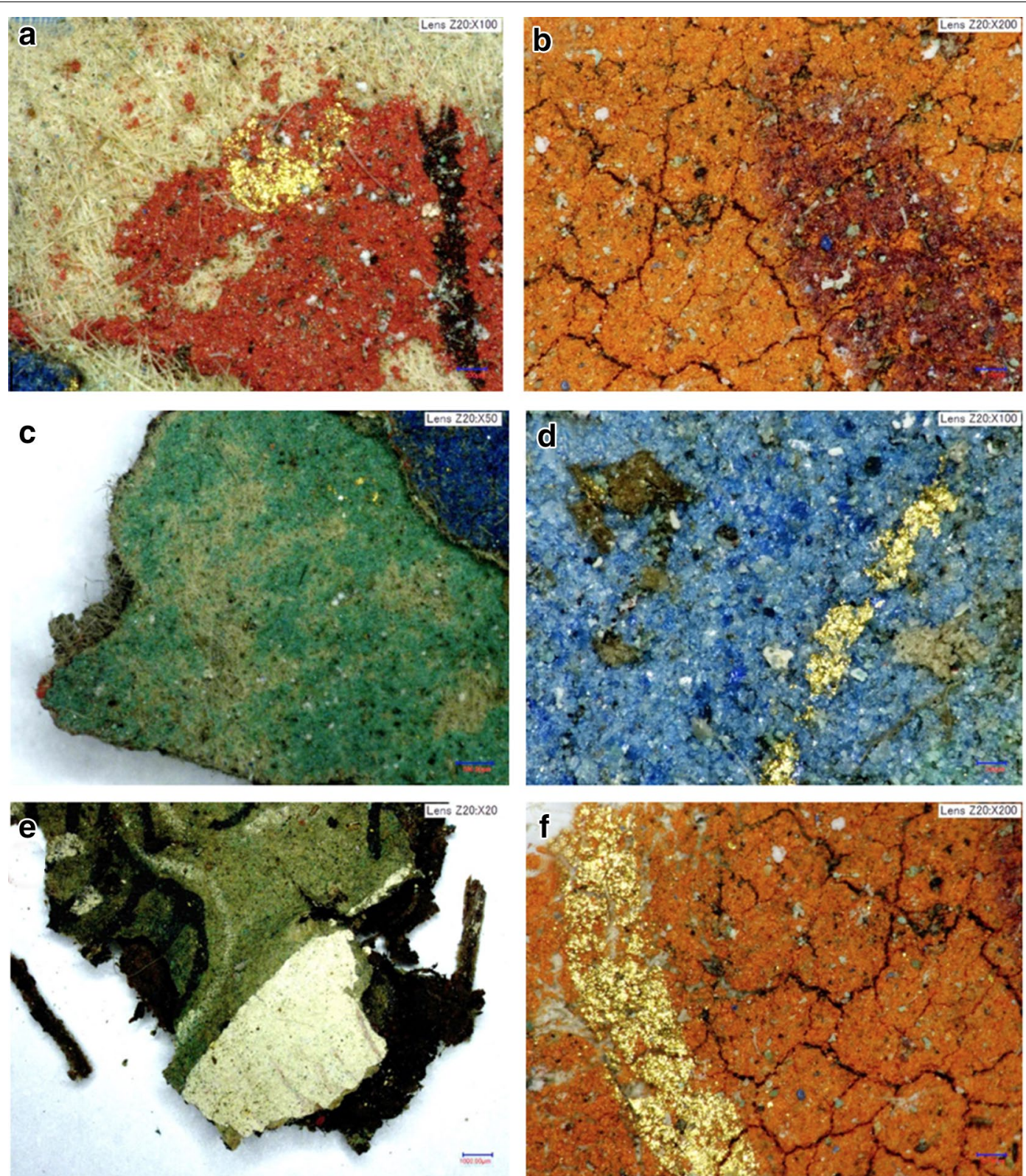

Fig. 2 Microscopic observation of pigments (a red pigment $\times 100$, b light red pigment $\times 200$, $\mathbf{c}$ green pigment $\times 50$, $\mathbf{d}$ blue pigment $\times 100$, e white pigment $\times 20$, $\mathbf{f}$ gilded material $\times 200$ )

\section{Chemical composition of the pigment}

SEM-EDS and Micro-Raman spectroscopy were used to identify the chemical composition of the pigments. Table 2 shows an overview of the pigments that were identified. The different colored samples were analyzed by micro-Raman spectroscopy to reveal the molecular composition of pigments [13]. Element information of each pigment was acquired by SEM-EDS. As shown in Fig. 2, samples were covered by pollutant minerals (mainly from soil), which caused the detection of elements such as $\mathrm{Si}, \mathrm{Ca}, \mathrm{K}$ and $\mathrm{Al}$ in samples.

The elements $\mathrm{Hg}$ and $\mathrm{S}$ were found by SEM-EDS, indicating that the red pigment consists of cinnabar (vermilion). The existing of cinnabar was also showed by Raman spectra (Fig. 3-red). A very strong band at $253 \mathrm{~cm}^{-1}$, arising from the stretching vibration of $\mathrm{Hg}-\mathrm{S}$ bond was 
Table 2 Chemical composition of the pigment

\begin{tabular}{|c|c|c|c|}
\hline Color & Elements detected by SEM-EDS & Raman bands/cm ${ }^{-1}$ & Pigment \\
\hline Red & $\mathrm{Hg}, \mathrm{S}, \mathrm{Si}, \mathrm{Ca}, \mathrm{K}, \mathrm{O}, \mathrm{C}$ & 253,347 & Cinnabar \\
\hline Light red & $P b, O$ & $120,161,224,307,478,546$ & Minium \\
\hline Green & $\mathrm{Cu}, \mathrm{Cl}, \mathrm{Ca}, \mathrm{Si}, \mathrm{K}, \mathrm{Al}, \mathrm{O}, \mathrm{C}$ & $\begin{array}{l}120,151,175,251,364,402,450,510,580,901,924 \\
976\end{array}$ & Paratacamite \\
\hline Blue & $\mathrm{Cu}, \mathrm{O}, \mathrm{C}$ & $249,400,765,836,940,1095,1432,1580$ & Azurite \\
\hline White & $\mathrm{Pb}, \mathrm{Cu}, \mathrm{Cl}, \mathrm{O}, \mathrm{C}$ & 1051 & Lead white \\
\hline Gilded material & $\mathrm{Au}, \mathrm{Ca}, \mathrm{K}, \mathrm{Fe}, \mathrm{O}, \mathrm{C}$ & - & Gold \\
\hline
\end{tabular}

Major elements are denoted in italics

clearly identified $[14,15]$. The use of cinnabar was known since Neolithic times $[16,17]$. Cinnabar has been mined in both prehistoric and historic China [18]. As one of the most widely used pigments in ancient China, cinnabar has been identified as the red pigment in famous Buddhist sites such as the Mogao Grottoes, Jokhang Monastery and other Buddhist rock-cut temples [19-21].

$\mathrm{Pb}$ appeared in the element analysis. The spectral bands at $120,161,224,307,478$, and $546 \mathrm{~cm}^{-1}$ are assigned to minium $\left(\mathrm{Pb}_{3} \mathrm{O}_{4}\right)$ (Fig. 3-light red). The strong absorption appearing at $540 \mathrm{~cm}^{-1}$ is attributed to the stretching of the $\mathrm{Pb}-\mathrm{O}$ bond $[22,23]$. Minium was usually used, besides cinnabar, as red pigment to achieve red colors, but it suffers easily from oxidation caused by environmental factors. The chemical reaction makes minium transform into plattnerite, and makes the color change from red to brown-black [24]. Fortunately, the sutra was kept inside the box, away from oxidizing agents, keeping the color stable.

$\mathrm{Cu}, \mathrm{Cl}, \mathrm{Ca}, \mathrm{Al}, \mathrm{K}$ were found as main elements in the green pigment sample, of which $\mathrm{Cu}$ and $\mathrm{Cl}$ came from the green pigment. Peaks at $120 \mathrm{~cm}^{-1}, 151 \mathrm{~cm}^{-1}$ and $175 \mathrm{~cm}^{-1}$ of green pigment can be assigned to $\mathrm{O}-\mathrm{Cu}-\mathrm{O}$ bending, while peak at $251 \mathrm{~cm}^{-1}$ is attributed to lattice mode. Peaks at $364 \mathrm{~cm}^{-1}$ and $402 \mathrm{~cm}^{-1}$ are attributed to the vibration of $\mathrm{Cu}-\mathrm{Cl}$ stretching; peaks at $450 \mathrm{~cm}^{-1}$ and $510 \mathrm{~cm}^{-1}$ belong to $\mathrm{Cu}-\mathrm{O}$ stretching. Peaks from $901 \mathrm{~cm}^{-1}$ to $976 \mathrm{~cm}^{-1}$ belong to hydroxyl deformation (Fig. 3-green). All the vibrations indicate that the pigment is paratacamite $[25,26]$. Paratacamite has been used as green pigment in the Buddhist Grottoes along the silk road [27].

$\mathrm{Cu}$ was characterized as the main element in the blue pigment. Raman spectra of characteristic bands of azurite could be found in 249, 400, 765, 836, 940, 1095, 1432 and $1580 \mathrm{~cm}^{-1}$ [28-30] (Fig. 3-blue). Azurite was the most important blue pigment in European paintings throughout the Middle Ages and Renaissance because of its fine texture and surface quality [31]. Azurite was widely used as a pigment in China from Tang dynasty in mural paintings and sculptures to replace lapis lazuli which was more expensive [32].

$\mathrm{Pb}$, as well as $\mathrm{Cu}$ and $\mathrm{Cl}$ were identified in the white pigment. Detection of $\mathrm{Cu}$ and $\mathrm{Cl}$ was caused by a coverage of small particles of green pigment. Vibration at $1051 \mathrm{~cm}^{-1}$ can be attribute to the absorption of lead white [33-35] (Fig. 3-white).

Gilded material was identified as gold. Gold was frequently used as gilding material in precious sutra in ancient China.

\section{Analysis of the paper fiber and textile}

Two different types of paper fiber were found. Observation by fiber analysis microscope (Fig. 4) shows that the fiber from the preface is straight. The fiber from the preface has an abundance of stone cells and smooth epidermal cells, indicating it is made from bamboo. Fiber from the inner page is thinner and longer, and it is covered by a gelatinous coating, which is characteristic of bark fiber [36].

The woven structure of the textile is five-heddle warp satin (Fig. 5) a typical structure for ancient silk fabric from the Tang dynasty, which was subsequently replaced by other weaving methods due to its complexity [37, 38]. SEM shows the shape of the cross section is a rectangle with round edge (Fig. 6), which is in accordance with silk (Bombyx mori) fiber [39, 40]. Several fibers were bonded together by the covering minerals, as a result, the surface was no longer smooth (Fig. 7). The typical vibration bands of silk are Amide I (stretching vibration of $\mathrm{C}=\mathrm{O}$ ), AmideII (bending vibration of $\mathrm{N}-\mathrm{H}$ ) and Amide III (stretching and bending vibration of $\mathrm{C}-\mathrm{N}$ and $\mathrm{N}-\mathrm{H}$ ), the bands have been found in $1636 \mathrm{~cm}^{-1}, 1525 \mathrm{~cm}^{-1}$ and $1381 \mathrm{~cm}^{-1}$ [41-43] (Fig. 8). It should be noted that the absorption bands of contamination appear on the surface of textile, indicating the appearance of mineral. 


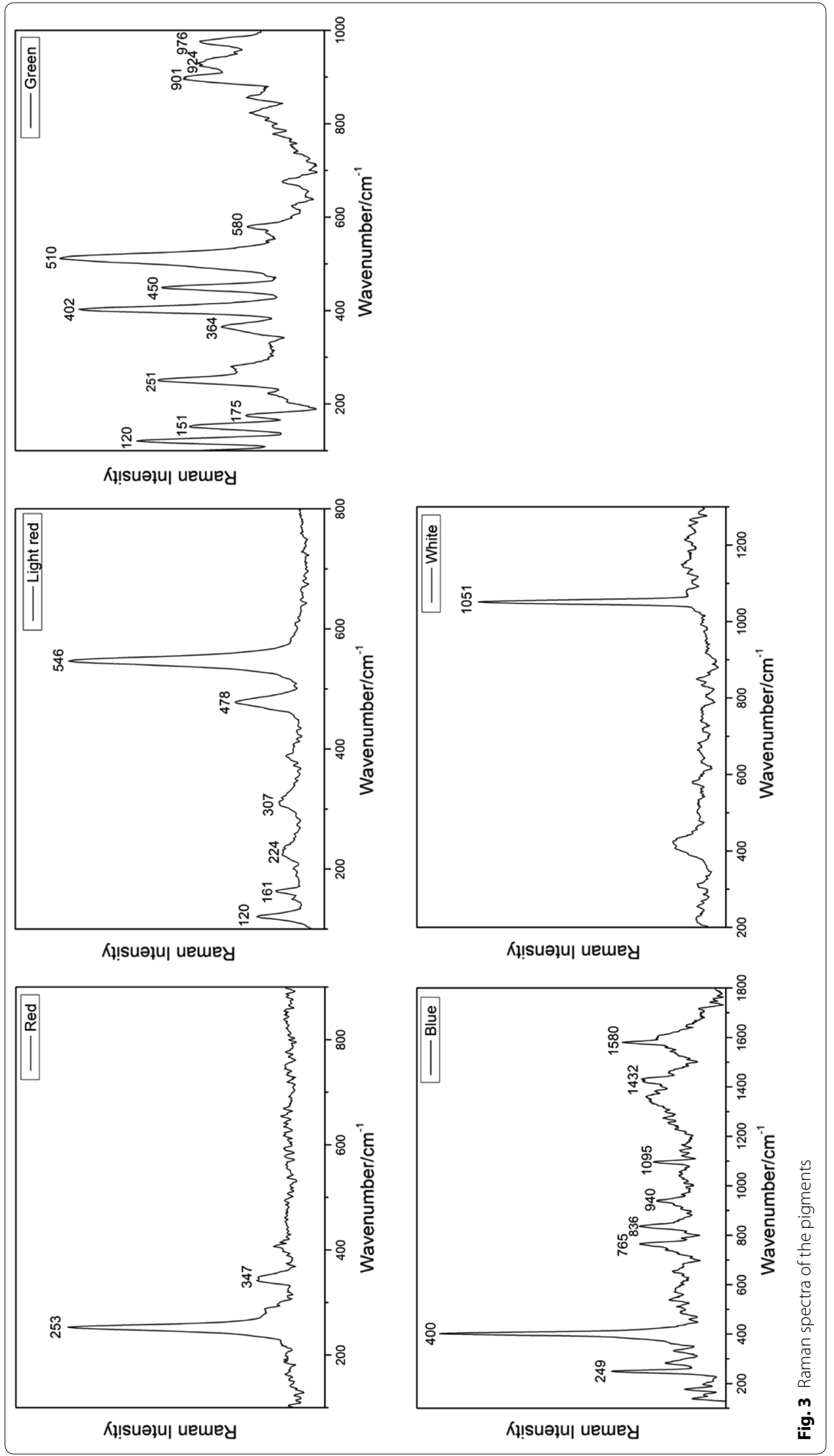




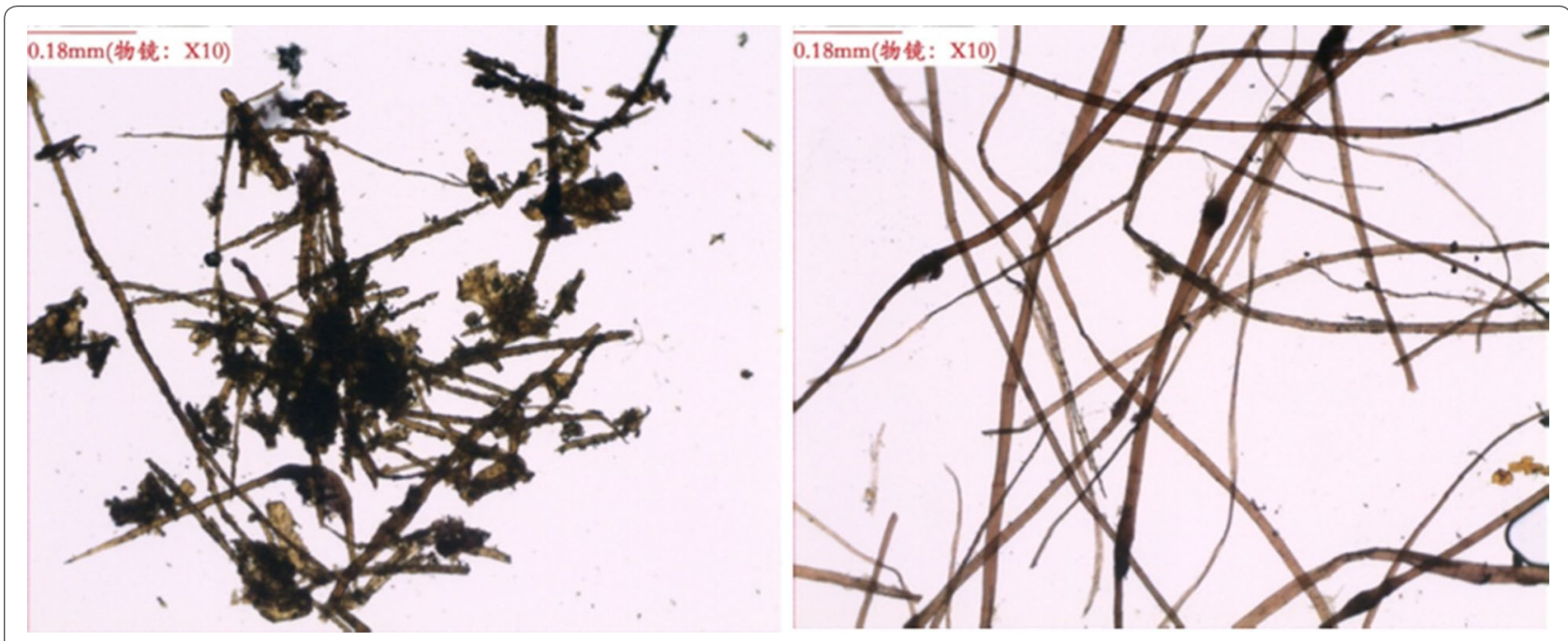

Fig. 4 a Left: paper fiber of the preface $\times 10$. $\mathbf{b}$ Right: paper fiber of the inner page $\times 10$

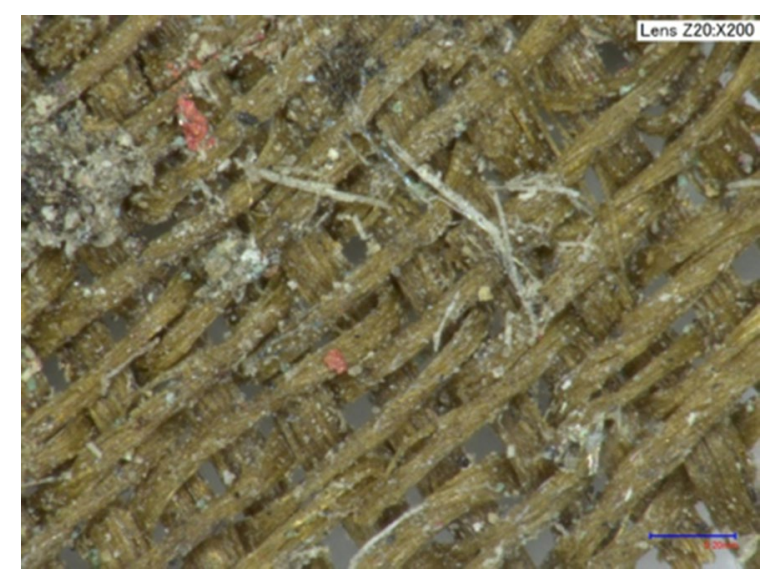

Fig. 5 Microscopic observation of the textile by OM $\times 200$

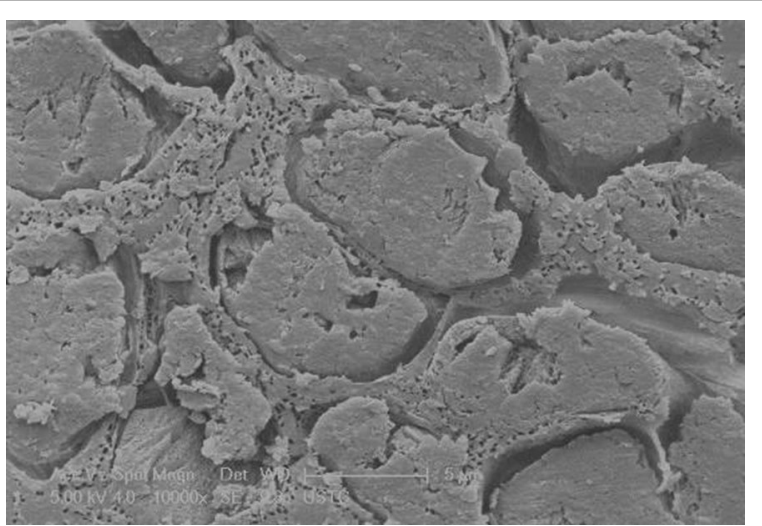

Fig. 6 Cross section of textile fiber

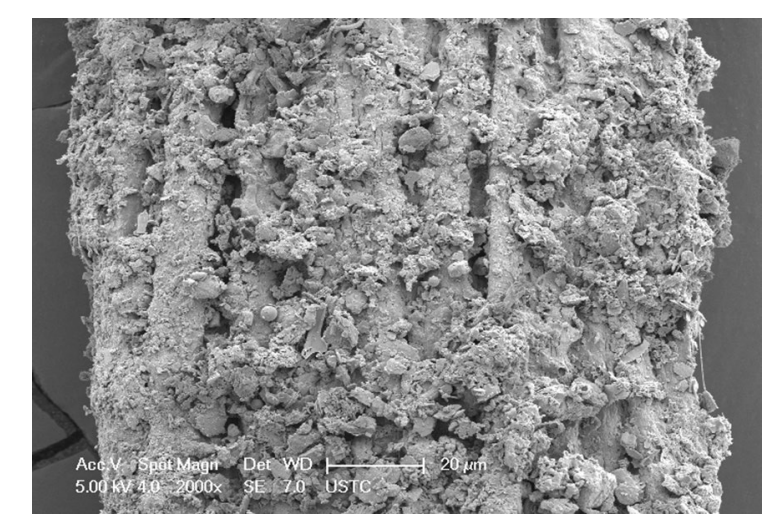

Fig. 7 Surface of the textile fiber

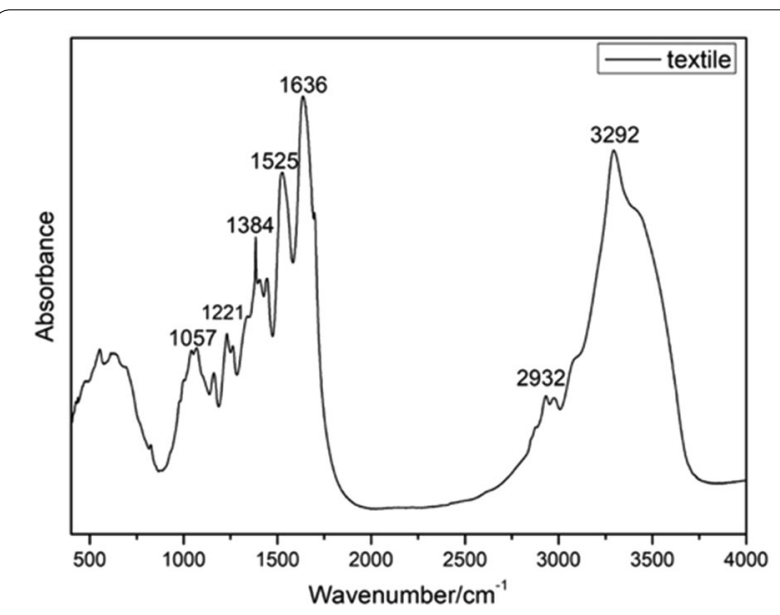

Fig. 8 FTIR spectra of the textile 


\section{Conclusions}

The Mahamayuri Vidyarajni Sutra, is a magnificent recondite treasure of Buddhism, believed to have special functions in prevention and cure of injuries caused by poison in ancient times. Five samples, taken from the sutra, were studied by several scientific techniques to characterize the materials and assess the preservation situation.

Different materials, such as cinnabar, minium, paratacamite, azurite, lead white and gold were identified as red pigment, light red pigment, green pigment, blue pigment, white pigment and gilded material, respectively. Two different paper fibers were found in the preface and inner page. The textile from the preface is a five-heddle warp satin and is made of silk (Bombyx mori). This complicated type of woven silk fabric, reserved for important uses was not employed after the Tang dynasty. The whole sutra is in a state of severe degradation.

This study shares insights into the materials employed, as well as assessing the preservation situation of the sutra and providing support for scientific protection and restoration schemes. Furthermore, restoration based on the research will benefit the study of Buddhism in ancient China.

\section{Abbreviations \\ OM: optical microscopy; Raman: micro-Raman spectroscopy combined with optical microscope; SEM-EDS: scanning electron microscopy in combina- tion with energy dispersive X-ray analysis; FTIR: Fourier transform infrared spectroscopy.}

\section{Acknowledgements}

Technical support from Instruments' Center for Physical Science in University of Science and Technology of China is greatly appreciated.

\section{Authors' contributions}

LL did data analysis and article written. DG did sample collection. ZY provided background, photos and samples. LX performed OM and SEM-EDS. ZZ performed analysis of FTIR, Raman. TE helped with the English language improvement. All authors read and approved the final manuscript.

\section{Funding}

This work is supported by China Ministry of Education Humanities and Social Sciences Project (18XJCZH011, 19YJCZH105), Natural Science Basic Research Program of Shaanxi (2019JQ-148), China Postdoctoral Science Foundation (2017M613197, 2018T111093, 2018M631186), Shaanxi Postdoctoral Science Foundation (2018BSHEDZZ116).

\section{Availability of data and materials}

All data generated or analyzed during this study are included in this published article.

\section{Competing interests}

The authors declare that they have no competing interests.

\section{Author details}

${ }^{1}$ Institute of Culture and Heritage, Northwestern Polytechnical University, 710000 Xi'an, China. ${ }^{2}$ Basic Research Center of Conservation Science, Department of History of Science and Scientific Archaeology, University of Science and Technology of China, Hefei 230026, China. ${ }^{3}$ Anhui Institute of Archaeology, Hefei 230601, China. ${ }^{4}$ Anhui Museum, Hefei 230061, China. ${ }^{5}$ Grimwade
Center of Cultural Materials Conservation, University of Melbourne, Melbourne 3010, Australia.

Received: 19 May 2019 Accepted: 26 September 2019

Published online: 02 October 2019

\section{References}

1. Xu LJ, Yao ZQ, Gong DC, Hu Y. Brief introduction of unearthed Mahamayuri Vidyarajni Sutra from Luan, Anhui. Study Cult Herit. 2010;17:302-4 (in Chinese).

2. Ren YX, Yang FX. Mahamayuri Vidyarajni Sutra and esoteric buddhism. J Shaanxi Norm Univ. 2012;41:107-11 (in Chinese).

3. Zhang L, Li WH. Introduction of Mahamayuri Vidyarajni Sutra in Henan museum. Cult Relics Central China. 2016;1:107-8 (in Chinese).

4. Huntington JC, Dina B. The circle of bliss: buddhist meditational art. Chicago: Serindia Publications; 2003. p. 34.

5. Little S. Mahamayuri Vidyaraja. Art Inst Chicago Mus Stud. 2004;30:36-95.

6. Wang HM. Mahamayuri Vidyarajni Sutra and its spreading in Dunhuang and Dazu. Dunhuang Res. 1996;4:42-52 (in Chinese).

7. Gong YX, Bai XJ, Liu L, Gong DC. Analytical study of the special crafts used in Ancient Tripitaka. J Cult Herit. 2015;16:928-33.

8. Liu Y, Chang R, Zheng H, Li M, Hu Z, Zhou Y, Wang B. Identification of proteinaceous binders in ancient tripitaka by the use of an enzyme-linked immunosorbent assay. Anal Sci Int J Japan Soc Anal Chem. 2016;32:735.

9. Hirotaka O, Yasukazu Y, Toshio N, Keiko F. AMS radiocarbon dating of ancient Japanese sutras. Nucl Instrum Methods B. 2000;172:736-40.

10. Hirotaka O, Toshio N, Toshio T. Radiocarbon dating of a sutra container excavated at the Minagi Daibutsuyama site, Fukuoka Prefecture, Japan. Nucl Instrum Methods B. 2004;223:686-90.

11. Coccato A, Costa M, Rousaki A, Clist B, Kaklins K, Bostoen K, Manhita A, Cardoso A, Barrocas DC, Candeias A, Moens L, Mirao J, Vandenabeele P. Micro-Raman spectroscopy and complementary techniques (hXRF, VPSEM-EDS, $\mu$-FTIR and Py-GC/MS) applied to the study of beads from the Kongo Kingdom (Democratic Republic of the Congo). J Raman Spectrosc. 2017:48:1468-78.

12. Gong DC, Yang HY, Li XC. Craft and filler of Xuanquan Paper in Gansu, Dunhuang. Cult Relics. 2014;9:85-90 (in Chinese).

13. Anna KK. An investigation of a unique group of painted silk banners from a Polish collection. J Raman Spectrosc. 2017;48:1725-31.

14. Barone G, Mazzoleni P, Cecchini A, Russo A. In situ Raman and pXRF spectroscopic study on the wall paintings of Etruscan Tarquinia tombs. Dyes Pigm. 2018;150:390-403.

15. Burgio L, Clark RJH. Library of FT-Raman spectra of pigments, minerals, pigment media and varnishes, and supplement to existing library of Raman spectra of pigments with visible excitation. Spectrochim Acta A. 2001;57:1491-521.

16. Anna KK. Non-destructive characterization of 17 th century painted silk banner by the combined use of Raman and XRF portable systems. $J$ Raman Spectrosc. 2015;46:317-21.

17. Dawson P. The vibrational spectrum of a-mercuric sulphide. Spectrochim Acta A. 1972;28:2305-10.

18. Emslie SD, Brasso R, Patterson WP, Valera AC, McKenzie A, Silva AM, Gleason JD, Blum JD. Chronic mercury exposure in Late Neolithic/Chalcolithic populations in Portugal from the cultural use of cinnabar. Sci Rep. 2015:5:14679. https://doi.org/10.1038/srep14679.

19. Sultan S, Kareen K, He L, Simon S. Identification of the authenticity of pigments in ancient polychromed artworks of China. Anal Methods. 2017; 5:814-25.

20. Li ZM, Wang LL, Ma QL, Mei JJ. A scientific study of the pigments in the wall paintings at Jokhang Monastery in Lhasa, Tibet, China. Herit Sci. 2014;2;21. https://doi.org/10.1186/s40494-014-0021-2.

21. Zhang YD, Wang JL, Liu HL, Wang XD, Zhang S. Integrated analysis of pigments on murals and sculptures in Mogao Grottoes. Anal Lett. 2015:15:2400-13.

22. Irazola M, Olivares M, Castro K, Maguregui M, Matrinze-Arkarazo I, Madariaga J. In situ Raman spectroscopy analysis combined with Raman and SEM-EDS imaging to assess the conservation state of 16 th century wall paintings. J Raman Spectrosc. 2012;43:1676-84. 
23. Edwards HGM, Dennis WF, Emma MN, Fernando RP. Minium; FT-Raman non-destructive analysis applied to an historical controversy. Analyst. 1999;124:1323-6.

24. Liu LY, Shen W, Zhang BJ, Ma Q. Microchemical study of pigments and binders in polychrome relics from Maiji Mountain Grottoes in Northwestern China. Microsc Microanal. 2016;4:845-56.

25. Frost RL, Martens WN, Kloprogge JT, Williams PA. Raman spectroscopy of the basic copper chloride minerals atacamite and paratacamite: implications for the study of copper, brass and bronze objects of archaeological significance. J Raman Spectrosc. 2002;33:801-6.

26. Tomasini EP, Landa CR, Siracusano G, Maier MS. Atacamite as a natural pigment in a South American colonial polychrome sculpture from the late XVI century. J Raman Spectrosc. 2013:4:637-42.

27. Su BM, Li ZX, Ma ZF, Li S, Ma QL. Pigment analysis of Kizil Grottoes. Dunhuang Res. 2000;1:65-75 (in Chinese).

28. Bicchieri M, Nardone M, Russo PA, Sodo A, Corsi M, Cristoforetti G, Palleschi V, Salvetti A, Tognoni E. Characterization of azurite and lazurite based pigments by laser induced breakdown spectroscopy and microRaman spectroscopy. Spectrochim Acta B. 2001;56:915-22.

29. Aru M, Burgio L, Rumsey MS. Mineral impurities in azurite pigments: artistic or natural selection. J Raman Spectrosc. 2014;45:1013-8.

30. Gutman M, Lesar-Kikelj M, Mladenovi A, et al. Raman microspectroscopic analysis of pigments of the Gothic wall painting from the Dominican Monastery in Ptuj (Slovenia). J Raman Spectrosc. 2014;45:1103-9.

31. Thompson D. The materials and techniques of medieval painting. New York: Dover Publications; 1956 (Chapter 3).

32. Ji J, Zhang JF. Origin and development of ancient Chinese blue pigment. Dunhuang Res. 2011;6:109-14 (in Chinese).

33. Badillo-Sanchez D, Baumann W. Comparative palette characterization of oil-on-canvas paintings of two well-known 19th-century Colombian artists by confocal Raman spectroscopy. J Raman Spectrosc. 2016;47:1540-7.
34. Petrova O, Pankin D, Povolotckaia A, Borisov E, Krivulko T, Kuraganov N, Kurochkin A. Pigment palette study of the XIX century plafond painting by Raman spectroscopy. J Cult Herit. 2019;37:233-7.

35. Muralha VSF, Burgio L, Clark RJH. Raman spectroscopy analysis of pigments on 16-17th c. Persian manuscripts. Spectrochim Acta A. 2012;92:21-8.

36. Wang JL. Fiber character and microscopy of Chinese paper. Beijing: Chinese Industry Impress; 1999. p. 310 (in Chinese).

37. Guo DB. Study of silk textile excavated from Masen Tomb. Silk. 1985;11:810 (in Chinese).

38. Luo Q, Lou SQ. Development of jacquard weave from fabrics from Liao Dynasty. Silk. 1998;12:46-8 (in Chinese).

39. Liu J, Guo DH, Zhou Y, Wu ZY, Li WY, Zhao F, Zheng XM. Identification of ancient textiles from Yingpan, Xinjiang, by multiple analytical techniques. J Archaeol Sci. 2011;38:1763-70.

40. Wu SQ, Li MY, Fang BS, Tong H. Reinforcement of vulnerable historic silk fabrics with bacterial cellulose film and its light aging behavior. Carbohydr Polym. 2012;88:496-501.

41. Li MY, Zhao Y, Tong T, Hou XH, Fang BS, Wu SQ, Shen XY, Tong H. Study of the degradation mechanism of Chinese historic silk (Bombyx mori) for the purpose of conservation. Polym Degrad Stabil. 2013;98:727-35.

42. Ravi J, Hills AE, Cerasoli E, Rakowska PD, Ryadnov MG. FTIR markers of methionine oxidation for early detection of oxidized protein therapeutics. Eur Biophys J. 2011;3:339-45.

43. Arai T, Freddi G, Innocenti R, Tsukada M. Biodegradation of Bombyx mori silk fibroin fibers and films. J Appl Polym Sci. 2004;4:2383-90.

\section{Publisher's Note}

Springer Nature remains neutral with regard to jurisdictional claims in published maps and institutional affiliations.

\section{Submit your manuscript to a SpringerOpen ${ }^{\circ}$ journal and benefit from:}

- Convenient online submission

- Rigorous peer review

- Open access: articles freely available online

- High visibility within the field

- Retaining the copyright to your article

Submit your next manuscript at $\boldsymbol{\nabla}$ springeropen.com 